\title{
EFFECTIVENESS OF BREATHING RELAXATION TO RELIEVE ANXIETY IN ELDERLY AT UPT PSTW BONDOWOSO
}

\author{
Fika Indah Prasetya 1), Shelia R Utami 2) \\ 1)Lecturer of School of Nursing Stikes Bhakti AI Qodiri, Jember \\ 2)Student of School of Nursing, Stikes Bhakti Al Qodiri Jember \\ Corresponding email :
}

\begin{abstract}
BACKGROUND : Human aging process undergoes a change toward physical and mental dependence. Complaints that accompany the aging process become a sign of disease, usually accompanied by feelings of anxiety. Anxiety also arises in certain situations such as public speaking, high job pressures, facing exams. Anxiety disorders arise when the anxiety lasts a long time, changes in behavior, or the occurrenceof changes in body metabolism. This study is conducted to determine the effectiveness of breathinf relaxation to reduce anxiety in elderly.

SUBJECT AND METHODE : This is a quasy experimental research conducted with two groups pre test and post test design. This study incolving 43 respondents divided into control group for 20 resondents and the rest become the experimental group. The data collected using questionnaire and alayze by using Man Whitney test.

RESULTS : Based on the results of the research before the breathing relaxation in the mean score in the experimental group was 2.35 and in the control group was 2.2. While after breathing relaxation in mean value in experiment group is 2.70 and in control group is 2.70 Then obtained result $p$ value: $0.000<a 0.05$ concluded $\mathrm{H} 1$ accepted, meaning there is influence of deep breath relaxation
\end{abstract}

DISCUSSION : Based on the research results, deep breath relaxation can be used as an alternative to lower anxiety levels

Key words : anxiety, relaxation breathing, eldeerly

\section{INTRODUCTION}

Anxiety is an emotional response which full of worry and the source of threats or thoughts about something that is coming is unclear and not defined (Geist and Jeverson, 2011). Aging is a human proccess going through a period physical and mental dependence. Accompanied by complaints in the aging process is a sign of disease such as anxiety, depression or denial of the disease. Anxiety can also arise in certain situation such as public speaking, high work pressure, or facing exams. These condition can trigger anxiety to fear. Anxiety disorder arise if the anxiety continous for a long time, there are changes in behavior, or changes in the metabolism in elderly.

In 2050 it is estimated that the elderly population will increase 3 times from 2013. In 2000 the number of elderly people was around 5,300,000 (7.4\%) of the total population whereas in 2010 the number of elderly was $24,000,000(9.77 \%)$ of the total population, and by 2020 it is estimated that the number of elderly people reaches $28,800,000(11.34 \%)$ of the total population. Data from 
Central Statistic Agency (BPS) show that the elderly population in Indonesia in 2007 was reached 18.7 million, increased to 23.9 million in 2010 (9.77\%). In 2020 it is estimated to reach 28.8 millions of people. Data from BasicHealth Research showed that $11.6 \%$ af adult population are facing emotional disorder such depression and anxiety (Ministry of Health, 2009). Hermawan (2007) stated that ten or twenty years later by 2020 the estimated elderly population in Indonesia reached 28.8 million or $11.34 \%$ with life expectancy of arounf 71 years. As life expenctancy increases, the number of depression in eldeerly is also increases. Elderly is a process of growth and development of humans, starting from the baby, the age of children, adulthood and aging. The US census bureau estimates that Indonesia wil experience an increase in the nukber of elderly in $1990-2025$, which is $41.4 \%$ (Maryam, 2008).

Preliminary study held in UPT PSTW Bondowoso found that total number of elderly is 89 elderly. The results show that 7 out of 10 eldelry experiencing anxiety characterized by increased blood pressure, increased pulse rate, increased breathing frequency, and experiencing sleep disturbance. In this case the treatment to handling anxiety is needed. Interview results obtained that breathing relaxation techniques have not been implemented at UPT PSTW Bondowoso. From this pehnomenon, researchers are interest to bring up material on deep breathing relaxation therapy for eldelry. This study is conducted to determine the effectiveness of breathing relaxation technique to relieve anxiety in elderly.

\section{METHODE}

This is q quantitative experiment, conducted with quasy experimental design with pre test and post test with control group approach. This study involving 75 elderly living in UPT PSTW Bondowoso as participants who taken by purposive sampling. The data collected by using HARS (Hamilton Anxiety Rating Scale). The respondents were divided into control group and experimental group. Breathing relaxation technique were given to experimental group for a week. Prestest was done a day before treatment followed by post test. The collcted data then was analyzed using Man Whitney analisis.

\section{RESULTS AND DISCUSSION}

The results show that in experimental group 13 respondents (56.5\%) are 61-70 years old; 9 respondents (39.1\%) are $71-80$ years old and 1 respondent $(4.3 \%)$ is $81-90$ years old. While in the control group 11 respondents (50\%) are 61-70 years old, 8 respondents (36.4\%) are $71-80$ years old and 1 respondent (4.5\%) is 81 - 90 years old.

Based on research on anxiety before treatment, it was found that the elderly who experienced anxiety has mean value of 2.35; median value was 2.00 ; the mode value was 2 ; deviation standart is 0.487 ; 
the minimum value is 2 and the maximum value is 3 . Statistical anaysis using Mann Whitney show $\mathrm{p}$ value smaller than a 0.05 which mean that $\mathrm{Ho}$ rejected and $\mathrm{H} 1$ accepted, that deep breathing relaxation technicque affected level anxiety of elderly.

Based on the results study, the experimental group show the mean is 2.35 , the median value is 2.00 , the mode value is 2 with deviation standart of 0.487 and minimum and maximum value are 2 and 3 . While in the control group it is found that the mean value is 2.70 ; the median value is 3,00 ; the mode values is 3 ; deviation stadart 2.70 , the minimum value is 2 and the maximum values is 3 .

Relaxation breathing is the breathing activity by using abdomen muscle characterized by slow frequency, rhythmic and comfortable which is done by closing the eye. Relaxation techniques can be used with several methods. Relaxation breathing technique can be used with several methide to achieve optimal results with addition of other technique such as guided imagery. Guided imagery is a technique by means of one's imagination to achieve certain positive tranquility effect (Smelter, Bare, Hinle and cheever, 2010).

The results of pre test show that the respondents show that the anxiety level is severe. Then the researchers applied the deep breathing relaxation technique since it has been known can relieve level anxiety by relieve resporatory disorder llike hyperventlation, hypertension, heart disease, insomnia, dizziness or headache due to pressure and asthma.

Because of this techniques, slow breathing can hold the inspirationto the maximum so that it can reduce the intensity of pain. The data obtain that the applied techniques could relieve the anxiety level.

\section{CONCLUSION AND RECOMENDATION}

Before deep breating rlaxation techniques applied in to the respondents the mean value is 2.35 and after the treatment the mean value decrease to 2.00 . So it can be conclude that deep breathig relaxation technicque is effective in relieving the anxiety in elderly.

Recommendation from this study is that the nurse should teach and applied deep breathing relaxation technique to the eldelry so that their anxiety will relieve.

\section{REFERENCE}

Aprilya Dewi Kartika Sari, Subandi, 2015. Pelatihan Teknik Relaksasi untuk Menurunkan Kecemasan pada Primary Caregiver Penderita Kanker Payudara. Program Magister Profesi Psikologi Fakultas Psikologi, Universitas Gadjah Mada.

Chandra Kristianto Patasik, 2013. Efektifitas Teknik Relaksasi Nafas Dalam Dan Guided Imagery Terhadap Penurunan Nyeri Pada Pasien Post Operasi Sectio Caesare 
Dilrina Blu Rsup Prof. Dr. R. D. Kandou Manado. Program Studi IImu Keperawatan Fakultas Kedokteran, Universitas Sam Ratulangi Manado.

Dina Dewi SLI, Setyoadi, Ni Made Widastra, 2009. Pengaruh Teknik Relaksasi Nafas Dalam Terhadap Penurunan Persepsi Nyeri Pada Lansia Dengan Artritis Reumatoid. Universitas Brawijaya, Malang.

Manurung, Nixson, 2016. Terapi Reminiscence Solusi Pendekatan Sebagai Upaya Tindakan Keperawatan Dalam Meurunkan Kecemasan, Stress DanDepresi CV.Trans Info Media, Jakarta Timur.

Notoadmodjo, Soekiedjo. 2012. Metodologi Penelitian Kesehatan. PT Rineka Cipta. Jakarta

Nurul Hartini, 2012. Hubungan Antara Penerimaan Diri Dengan Kecemasan Menghadapi Dunia Kerja Pada Tunadaksa Di UPT RehabilitasiS osial. AirlanggaUniversity, Surabaya.

Nursalam. 2013. Metodologi Penelitianllmu Keperawatan, Ed 3, Selemba Medika, Jakarta Selatan

Pedek, Mustamir, 2009. Terapi Reminiscence jenis-jenis kecemasan. CV.Trans Info Media, Jakarta Timur 